\title{
Tomato yield as a function of water depths and irrigation suspension periods
}

\author{
Cícero J. da Silva ${ }^{1}$, José A. Frizzone ${ }^{2}$, César A. da Silva ${ }^{1}$, Adelmo Golynski ${ }^{1}$, \\ Luiz F. M. da Silva ${ }^{1} \&$ Clarice A. Megguer ${ }^{1}$
}

${ }^{1}$ Instituto Federal Goiano/Campus Morrinhos. Morrinhos, GO, Brasil. E-mail: cicero.silva@ifgoiano.edu.br (Corresponding author) - ORCID: 00000002-4067-6385; cesar.silva@ifgoiano.edu.br - ORCID: 0000-0002-8620-1975; adelmo.golynski@ifgoiano.edu.br - ORCID: 0000-0002-1913-9673; luizfelipeagroif@outlook.com - ORCID: 0000-0002-7329-3292; clarice.megguer@ifgoiano.edu.br- ORCID: 0000-0001-9203-183X

${ }^{2}$ Universidade de São Paulo/Escola Superior de Agricultura “Luiz de Queiroz”. Piracicaba, SP, Brasil. E-mail: frizzone@usp.br - ORCID: 0000-0002-4251-1496

\begin{abstract}
Irrigation management is essential for tomato fruits yield and quality. Therefore, the aim of this study was to evaluate the yield of tomatoes for industrial processing, 'BRS Sena' hybrid, subjected to water depths and irrigation suspension periods before harvest, irrigated by subsurface drip irrigation, in Goiás, Brazil (17० 49' 19.5" S and 49 $\left.12^{\prime} 11.3^{\prime \prime} \mathrm{W}\right)$, in 2015 and 2016 . The experiments were conducted under a randomized complete block design, with four replications, in split plots. Five irrigation levels (50, 75, 100, 125 and $150 \%$ of crop evapotranspiration) were evaluated in the plots and five irrigation suspension periods $(0,7,14,21$ and 28 days before harvest) were evaluated in the subplots. At 125 days after transplanting the seedlings, the yields of green, mature, rotten fruits and total yield, water productivity and percentages of green, mature and rotten fruits were evaluated. The highest total fruit yields $\left(105.86\right.$ and $\left.58.60 \mathrm{t} \mathrm{ha}^{-1}\right)$ were obtained with water replacements ranging from $125.47(615.09 \mathrm{~mm})$ to $132.11(564.00 \mathrm{~mm})$ of crop evapotranspiration, in the first and second year of experiment, respectively. Growing plants under water deficit and excess increased the incidence of rotten fruits and decreased that of mature fruits. Pre-harvest irrigation suspension reduced crop yield and incidence of green fruits and increased the incidence of rotten fruits. The highest water productivity by the crop occurred under water deficit, management that may be interesting for regions with water restrictions.
\end{abstract}

Key words: Solanum lycopersicon L., subsurface drip irrigation, industrial tomato, irrigation management, crop evapotranspiration

\section{Produtividade do tomateiro em função de lâminas e períodos de suspensão da irrigação}

RESUMO: O manejo da irrigação é essencial para a produtividade e qualidade dos frutos de tomateiro. Objetivou-se neste estudo avaliar a produtividade do tomateiro para processamento industrial "Híbrido BRS Sena" submetido à lâminas e períodos de suspensão da irrigação antes da colheita, irrigado por um

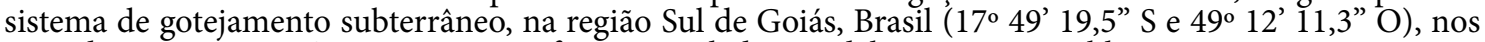
anos de 2015 e 2016. Os experimentos foram instalados no delineamento em blocos ao acaso, com quatro repetições, em parcelas subdivididas. Nas parcelas avaliaram-se cinco níveis de irrigação $(50,75,100,125$ e $150 \%$ da evapotranspiração da cultura) e nas subparcelas cinco períodos de suspensão da irrigação $(0,7$, 14,21 e 28 dias antes da colheita). Aos 125 dias após o transplantio das mudas avaliou-se a produtividade de frutos verdes, maduros, podres e total, a produtividade da água e as percentagens de frutos verdes, maduros e podres. As maiores produtividades totais de frutos $\left(105,86\right.$ e $\left.58,60 \mathrm{t} \mathrm{ha}^{-1}\right)$ foram obtidas com reposições hídricas que variaram de 125,47 $(615,09 \mathrm{~mm})$ e 132,11\% (564,00 mm) da evapotranspiração da cultura, nos dois experimentos, respectivamente. As plantas cultivadas sob déficit e excesso hídrico, aumentaram a incidência de frutos podres e diminuíram a de frutos maduros. A suspensão da irrigação antes da colheita diminuiu a produtividade da cultura, aumentou a incidência de frutos podres e diminuiu a incidência de frutos verdes. A maior produtividade da água ocorreu sob déficit hídrico, manejo que pode ser interessante para regiões com restrições hídricas.

Palavras-chave: Solanum lycopersicon L., gotejamento enterrado, tomateiro industrial, manejo da irrigação, evapotranspiração da cultura 


\section{INTRODUCTION}

Water replacement in the soil by irrigation, in appropriate amount and time, is decisive for success of tomato crop because water is one of the factors that most limit the development, yield and industrial quality of tomato fruits (Koetz et al., 2010; Moreira et al., 2012; Nangare et al., 2016).

In Italy, Patanè et al. (2011) concluded that, under water deficit, industrial tomato yield is severely compromised and that irrigation during the entire cycle promotes higher yields, whereas longer periods of irrigation suspension prior to harvest lead to lower yields, due to lower fruit weight and abortion of flowers and fruits. In Morrinhos, GO, Silva et al. (2018) concluded that the higher the water stress index of the crop, the lower the yield of the industrial processing tomato hybrid ('BRS Sena').

These results corroborate with those of Monte et al. (2013), Silva et al. (2014), Morales et al. (2015) and Rebouças Neto et al. (2017), under field conditions in Rio de Janeiro-RJ, Catolé do Rocha-PB, Lavras-MG and Fortaleza-CE, with the hybrid 'Débora Plus', long-life type, 'Heinz 9498' and 'Caline IPA 6', 'TOM - 684' and 'M - 82' and 'Dominador F1', respectively. All studies verified linear increase in the yield as irrigation levels increased from 30 to $120 \%$ of Reference Evapotranspiration (ETo), from 50 to $150 \%$ ETo, from 25 to $100 \%$ field capacity and from 40 to $120 \%$ of Crop Evapotranspiration (ETc), respectively.

Tomato water requirements are related to the hybrid, development stage and edaphoclimatic conditions to which the crop is subjected (Koetz et al., 2008; Bacallao \& Fundora, 2014). Thus, the present study aimed to evaluate the yield of the industrial processing tomato hybrid 'BRS Sena' subjected to irrigation depths and suspension periods prior to harvest, under subsurface drip irrigation in a Oxisols in the Southern region of Goiás, Brazil.

\section{Material And Methods}

The experiments were conducted in the years 2015 (June to October) and 2016 (May to September) at the Goiano Federal Institute, Campus of Morrinhos, GO, Brazil, situated at $17^{\circ}$ $49^{\prime} 19.5^{\prime \prime} \mathrm{S}$ and $49^{\circ} 12^{\prime} 11.3^{\prime \prime} \mathrm{W}$, at altitude of $885 \mathrm{~m}$. The local climate is Aw, semi-humid tropical, with rainy summer and dry winter, according to Köppen's classification.

The study was conducted in an area of Oxisols (EMBRAPA, 2013), with bulk density of $1.16 \mathrm{~kg} \mathrm{dm}^{-3}$ and moisture contents of $0.36 \mathrm{~m}^{3} \mathrm{~m}^{-3}(-10 \mathrm{kPa})$ at field capacity and $0.23 \mathrm{~m}^{3} \mathrm{~m}^{-3}(-1500$ $\mathrm{kPa})$ at permanent wilting point, in the $0-30 \mathrm{~cm}$ layer. Soil tillage was carried out conventionally in 2015, whereas direct seeding system was adopted in 2016. Soil fertilization was performed according to soil analysis (Table 1) for an expected yield of $130 \mathrm{t} \mathrm{ha}^{-1}$ (CFSGO, 1988).

In 2015 , liming was done (broadcast) in the entire area, 51 days before transplanting. In 2016, it was not necessary to correct soil acidity. In both years of study, fertilization was performed in the planting furrow, three days before transplanting the seedlings, and top-dressing fertilization was applied through fertigation, half at 22 days after transplanting (DAT) (urea and potassium chloride - fertigation) and half at 35 DAT (calcium nitrate and potassium chloride - fertigation).

At 26 days after sowing, the seedlings were transplanted to the furrow dug for the dripline and fertilizers, after they were covered with soil at field capacity. Until 8 DAT, plants were daily irrigated and, from 8 to 25 DAT, were irrigated on alternate days, replacing $100 \%$ of crop evapotranspiration (ETc), in order to ensure seedling establishment.

The experiments were set up in a randomized complete block design, with four replicates, in split plots in a $5 \times 5$ arrangement. Five irrigation levels equal to 50, 75, 100, 125 and $150 \%$ ETc were applied in the plots, whereas five periods of irrigation suspension $(0,7,14,21$ and 28 days prior to harvest) were applied in the subplots. Each experimental plot consisted of five subplots, and each subplot comprised three 5.5-m-long plant rows spaced at $1.10 \mathrm{~m}$. Plants were spaced at $0.30 \mathrm{~m}$ in the planting row, totaling 18 plants per row, 54 plants per subplot, 270 plants per plot, and 5400 plants in the experiment, which results in a stand of approximately 30,303 plants ha ${ }^{-1}$. The blocks and plots were separeted by 6 and $4 \mathrm{~m}$, respectively.

The drip system was installed at $0.20 \mathrm{~m}$ depth, using one pressure-compensating emitter per plant, with flow rate of $2.2 \mathrm{~L} \mathrm{~h}^{-1}$ and an anti-siphon system, operating at $150 \mathrm{kPa}$ pressure. ETc was determined through the mass variation of five weighing lysimeters, with capacity for $52 \mathrm{~L}$, diameter of $32.5 \mathrm{~cm}$ and precision of $10 \mathrm{~g}$, which were filled with air-dried soil from the experimental area (0-15 cm layer) and cultivated with one tomato plant. The irrigation times of each treatment were calculated according to ETc, wetted strip width, spacing, dripper flow rate and irrigation depth (treatments). Meteorological data were monitored in an automatic meteorological station, located about $400 \mathrm{~m}$ away from the experiment.

From 97 days after transplanting, irrigation was gradually suspended. Initially, the suspension was applied to the subplots of 28 days prior to harvest. Seven days after, it was applied to

Table 1. Results of chemical and physical analysis for the soil of the experimental area, in Morrinhos, GO, Brazil

\begin{tabular}{|c|c|c|c|c|c|c|c|c|c|c|c|c|}
\hline \multirow{3}{*}{$\begin{array}{c}\text { Sample } \\
\text { (cm) }\end{array}$} & \multicolumn{8}{|c|}{ Chemical analysis } & \multirow{3}{*}{ 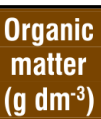 } & \multicolumn{3}{|c|}{ Particle size } \\
\hline & \multirow{2}{*}{$\begin{array}{c}\mathrm{pH} \\
\text { water }\end{array}$} & $\mathbf{P}$ & K & $\mathrm{Na}$ & $\mathrm{Ca}$ & $\mathrm{Mg}$ & Al & $\mathrm{H}+\mathrm{Al}$ & & Sand & Silt & Clay \\
\hline & & \multicolumn{3}{|c|}{$\left(\mathrm{mg} \mathrm{dm^{-3 } )}\right.$} & \multicolumn{4}{|c|}{$\left(\mathrm{cmol}_{\mathrm{c}} \mathrm{dm}^{-3}\right)$} & & \multicolumn{3}{|c|}{$\left(\mathrm{g} \mathrm{kg}^{-1}\right)$} \\
\hline & & & & & \multicolumn{4}{|c|}{ 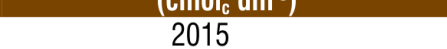 } & & \multicolumn{3}{|c|}{$(\mathrm{g} k \mathrm{~g})$} \\
\hline $0-20$ & 5.7 & 2.6 & 44.0 & 9.0 & 2.9 & 1.2 & 0 & 2.6 & 31.1 & 486 & 100 & 414 \\
\hline $20-40$ & 5.5 & 1.5 & 35.0 & 8.0 & 1.8 & 0.8 & 0.1 & 2.9 & 26.0 & 494 & 121 & 385 \\
\hline \multicolumn{13}{|c|}{2016} \\
\hline $0-20$ & 6.4 & 13.3 & 94.4 & 87.0 & 3.2 & 1.2 & 0 & 1.7 & 37.8 & - & - & - \\
\hline $20-40$ & 5.7 & 13.3 & 6.5 & 88.0 & 0.8 & 0.8 & 0 & 2.3 & 32.6 & - & - & - \\
\hline
\end{tabular}

Methodology used: $\mathrm{pH}$ - Soil: water suspension (1:2.5); P, K and $\mathrm{Na}-$ Mehlich 1; Ca, Mg and Al - IM potassium chloride at pH 7.0; $\mathrm{H}+\mathrm{Al}-0.5 \mathrm{M}$ calcium acetate at pH 7.0; Organic matter - Wet oxidation (organic carbon content x 1.724) 
the subplots of 21 days and so on, until reaching the harvest date, when the plots with zero days of irrigation suspension were irrigated 12 hours prior to harvest.

Fruit yield evaluations were carried out at 125 DAT (harvest). Harvest was performed manually in plants from the central row of the subplot. After being harvested, the fruits were separated into green, mature and rotten, and their masses were determined on a scale with capacity for $100 \mathrm{~kg}$ and precision of $0.01 \mathrm{~kg}$.

Data of mass of fruits harvested per treatment, number of harvested plants per subplot and proportional number of plants $\mathrm{ha}^{-1}$, based on the transplanting spacing $(0.3 \times 1.10 \mathrm{~m})$, were used to estimate yields ( $\mathrm{t} \mathrm{ha}^{-1}$ ) of green fruits (GFY), mature fruits (MFY) and rotten fruits (RFY) (Eq. 1). The total fruit yield (TFY) was estimated by summing the yields of green, mature and rotten fruits.

$$
\mathrm{Y}=\left(\frac{30303.03 \mathrm{MFH}}{\mathrm{NPH}}\right) / 1000
$$

where:

$\mathrm{Y}$ - yield of green, mature and rotten fruits, $\mathrm{t} \mathrm{ha}^{-1}$;

30303.03 - number of plants ha ${ }^{-1}$ estimated by using seedling transplanting spacing $(0.30 \times 1.10 \mathrm{~m})$;

MFH - mass of fruits harvested in each subplot, either green, mature or rotten, $\mathrm{kg}$;

$\mathrm{NPH}$ - number of plants harvested in the central row of each subplot; and,

1000 - yield conversion factor from $\mathrm{kg}$ to $\mathrm{t}$.

The percentages of yield of green (\%GFY), rotten (\%RFY) and mature (\%MFY) fruits were estimated by the relationship between GFY, RFY, MFY and TFY (Eq. 2).

$$
\% \mathrm{PY}=\left(\frac{\mathrm{FY}}{\mathrm{TFY}}\right) 100
$$

where:

$\% \mathrm{PY}$ - percentages of yield of green, rotten or mature fruits; FY - yield of green, rotten or mature fruits, $\mathrm{t} \mathrm{ha}^{-1}$;

TFY - total fruit yield, $\mathrm{t} \mathrm{ha}^{-1}$; and,

100 - data conversion factor from decimal to percentage.

Water productivity (WP) was calculated based on the relationship between TFY $\left(\mathrm{kg} \mathrm{ha}^{-1}\right)$ and the proportional total water volume of each treatment $\left(\mathrm{m}^{3} \mathrm{ha}^{-1}\right)$, summing all irrigations carried out along the experiment in each treatment (Eq. 3).

$$
\mathrm{WP}=\frac{\mathrm{TFY}}{\mathrm{V}}
$$

where:

WP - water productivity, $\mathrm{kg} \mathrm{m}^{-3}$;

TFY - total fruit yield, $\mathrm{kg} \mathrm{ha}^{-1}$; and,

$\mathrm{V}$ - water volume applied per hectare in each treatment, $\mathrm{m}^{3}$.

The parameters evaluated were subjected to analysis of variance (Fisher's $F$ test) at 0.05 significance level $(\mathrm{p}<0.05)$, using the program SISVAR (Variance Analysis System) (Ferreira, 2011). When there was significant effect of treatments on the parameters evaluated, polynomial regression analysis was carried out for primary (irrigation levels) and secondary treatments (irrigation suspension periods). The regression model was selected according to the level of significance up to 0.05 probability level by $\mathrm{F}$ test and highest coefficient of determination $\left(\mathrm{R}^{2}\right)$.

\section{Results AND Discussion}

The meteorological station, along the experiments, recorded maximum and minimum temperatures of 35.4 and $11^{\circ} \mathrm{C}$, with rainfall of $86 \mathrm{~mm}$ in 2015 , and maximum and minimum temperatures of 34.1 and $8.2^{\circ} \mathrm{C}$, with rainfall of $27.6 \mathrm{~mm}$ in 2016. The cumulative values of ETc obtained in the lysimeters, during the experiments (125 days), were 490.2 and $426.9 \mathrm{~mm}$, while those of reference evapotranspiration (ETo) calculated by Penman-Monteith, according to Allen et al. (1998), were 474.1 and $492.2 \mathrm{~mm}$, in the years 2015 and 2016, respectively. Irrigation depths (treatments) varied proportionally to ETc and to the irrigation suspension periods prior to harvest, in both years of study.

In the first year, no typical symptoms of Begomovirus were observed in the crop. In the second year, despite the intensification in white fly control, there was a strong pressure of the pest on tomato plants, which culminated with high incidence of symptoms of virus disease caused by a complex of virus of the genus Begomovirus, with typical symptoms of roughness, deformation, leaf curling, leaf area reduction and consequently lower growth, lower absorption of water and nutrients, and lower yield (Inoue-Nagata, 2005). This fact explains the lower water consumption and lower yields of the tomato hybrid 'BRS Sena' in 2016, compared to 2015.

There was no significant interaction $(\mathrm{p}>0.05)$ between irrigation replacement levels $(\% \mathrm{ETc}) \mathrm{x}$ irrigation suspension periods for any of the parameters evaluated, regardless of the year studied. In 2015, irrigation depths had significant effect ( $p \leq 0.01)$ on all parameters evaluated, except GFY, \%MFY and RFY, which were not significantly ( $p>0.05)$ affected by the irrigation levels. Irrigation suspension periods prior to harvest caused significant statistical differences $(\mathrm{p} \leq 0.01)$ on GFY, TFY, \%RFY and $(\mathrm{p} \leq 0.05)$ on MFY and \%GFY. However, for RFY, \%MFY and WP, there were no least significant differences. In 2016, the irrigation levels and suspension periods prior to harvest caused significant effects at $\mathrm{p} \leq 0.01$ on all yield parameters evaluated, except $\% \mathrm{GFY}$, which was significantly affected at $\mathrm{p} \leq 0.05$.

Both deficit and excess irrigation compromised the yield of the tomato hybrid 'BRS Sena', regardless of the year evaluated. The highest GFY, MFY and TFY estimated in the first year were 18.25, 69.96 and $105.86 \mathrm{t} \mathrm{ha}^{-1}$, with irrigation replacement of $100.15(490.0 \mathrm{~mm}), 125.47(615.1 \mathrm{~mm})$ and $123.96 \%$ (607.7 mm) of ETc, respectively (Figure 1A). In 2016, the highest values of MFY and TFY and lowest value of RFY were estimated at $46.31,58.60$ and $3.36 \mathrm{t} \mathrm{ha}^{-1}$, with irrigations of $128.48(548.5 \mathrm{~mm}), 132.1(564.0 \mathrm{~mm})$ and $124.0 \%(529.4 \mathrm{~mm})$ of ETc, respectively. However, GFY increased linearly with increasing levels of irrigation (Figure 1B). 


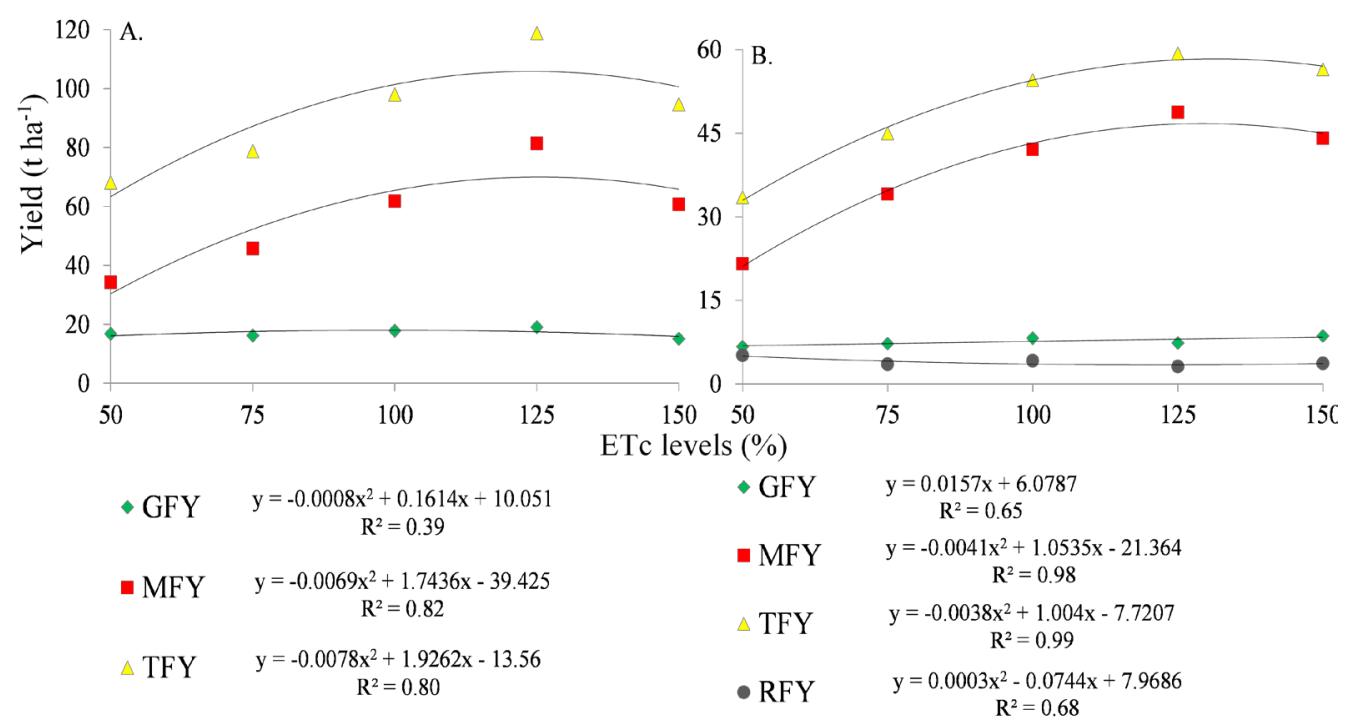

Figure 1. Green fruit yield (GFY), mature fruit yield (MFY) and total fruit yield (TFY) in 2015 (A) and in 2016 (B), of tomato plants at 125 days after transplanting, as a function of irrigation replacement levels (\%ETc), in Morrinhos, GO, Brazil

The results of yield corroborate those found by Koetz et al. (2008), Moreira et al. (2012) and Silva et al. (2018), in Cerrado area of Jataí, Ipameri and Morrinhos in Goiás, with the hybrid 'Heinz 9498', cultivar 'Hypeel' and hybrid 'BRS Sena', respectively. These authors concluded that, under water deficit, tomato yield is compromised. The results are also similar to those observed by Morales et al. (2015), in Lavras, MG, in a greenhouse with the tomato cultivars 'TOM - 64' and 'M - 82', and similar to those found by Monte et al. (2013) and Rebouças Neto et al. (2017) with hybrid tomatoes ('Débora Plus' - long-life type, and 'Dominador F1'), grown under field conditions in Rio de Janeiro and Fortaleza, respectively. The results also agree with those reported by Patanè et al. (2011), who conducted a study in Italy and concluded that, under water deficit ( $50 \% \mathrm{ETc})$, industrial processing tomato yield is severely damaged (40\% lower) compared to the yield obtained under replacement of $100 \%$ ETc.

The highest incidence of mature fruits was estimated at 65.41 and $80.88 \%$, with irrigation equivalent to 125.36 and $122.7 \% \mathrm{ETc}$, in the first and second experiments, respectively.
The lowest \%RFY in 2015 and 2016 and lowest \%GFY in 2016 were estimated at $17.65,6.24$ and $12.86 \%$, with irrigation corresponding to $115.87,121.18$ and $124.73 \%$ ETc, respectively (Figures 2A and B). However, in the first experiment, there was a decreasing linear effect for \%GFY as the levels of irrigation increased (Figure 2A).

The increase in the percentage of green fruits in treatments under water deficit was due to the large amount of small green fruits, which were verified in the treatments. Higher incidences of rotten fruits in treatments with irrigation deficit and excess, especially in the first year, may be related to calcium deficiency (black bottom) in these treatments because, at harvest, it was not possible to distinguish which fruits were rotten due to calcium deficiency and which were rotten due to other causes. In treatments with deficit irrigation ( $50 \% \mathrm{ETc})$, the number of rotten fruits may also have been influenced by the earlier maturation of part of the fruits, which caused increased rotting due to the harvesting period.

The incidence of rotten fruits corroborates the results found by Sá et al. (2005), with the hybrid 'Raisa N', under protected

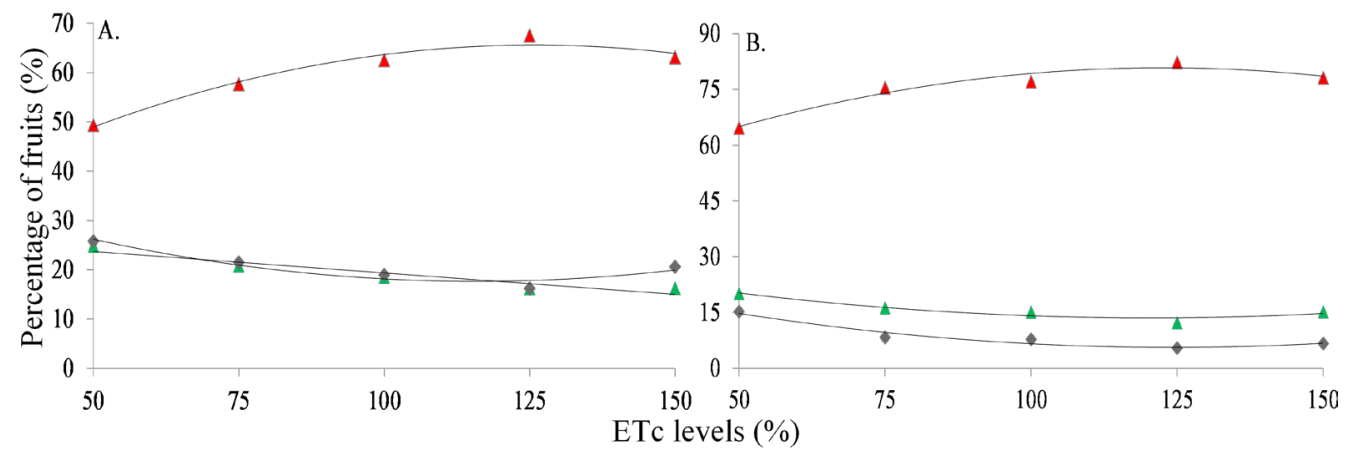

$$
\begin{aligned}
& \begin{array}{cccc}
\Delta \% \text { GFY } & y=-0.0869 x+28.039 \\
\mathrm{R}^{2}=0.91 & \Delta \% \mathrm{GFY} & \mathrm{y}=0.0013 \mathrm{x}^{2}-0.3243 \mathrm{x}+33.086 \\
\mathrm{R}^{2}=0.91
\end{array} \\
& \begin{array}{ccc}
\text { - } \mathrm{RFY} \quad \mathrm{y}=0.002 \mathrm{x}^{2}-0.4558 \mathrm{x}+44.06 \\
\mathrm{R}^{2}=0.92
\end{array} \leftrightarrow \mathrm{RFY} \quad \mathrm{y}=0.0017 \mathrm{x}^{2}-0.4121 \mathrm{x}+31.206 \\
& \begin{array}{ccc}
\Delta \% \text { MFY } \quad \mathrm{y}=-0.0029 \mathrm{x}^{2}+0.7271 \mathrm{x}+19.835 & \Delta \% \mathrm{MFY} & \mathrm{y}=-0.003 \mathrm{x}^{2}+0.7362 \mathrm{x}+35.715 \\
\mathrm{R}^{2}=0.97 & \mathrm{R}^{2}=0.95
\end{array}
\end{aligned}
$$

Figure 2. Percentages of green (\% GFV), rotten (\% RFY) and mature fruits (\%MFY) in 2015 (A) and 2016 (B), of tomato plants at 125 DAT, as a function of irrigation replacement levels (\%ETc), in Morrinhos, GO, Brazil 
environment in Lavras, MG; these authors observed that both water deficit and excess increase the incidence of this problem.

In relation to the irrigation suspensions at the end of the cycle, there were linear reductions in GFY and TFY as the irrigation suspension periods increased, regardless of the year (Figures 3A and B). For MFY, the crop behaved differently from one year to the other. In the first year, the longest and shortest periods without irrigation before harvesting increased MFY, and its lowest value was estimated at $51.87 \mathrm{t} \mathrm{ha}^{-1}$, with suspension of irrigation at 19 days before harvest (Figure 3A). In 2016, the highest MFY (41.14 $\mathrm{t} \mathrm{ha}^{-1}$ ) was estimated with irrigation suspension at 13 days before harvest, while the lowest incidence of RFY was estimated at $2.46 \mathrm{t} \mathrm{ha}^{-1}$, with irrigation suspension at 14 days before harvest (Figure $3 \mathrm{~B}$ ).

According to Figure $3 \mathrm{~B}$, it is evident that the occurrence of rotten fruits increases when the incidence of mature fruits decreases. Increase of RFY in the shortest periods of irrigation suspension may be related to the higher moisture content in these treatments, compared to the others, whereas in the longest periods without irrigation, the increase may be related to the earlier maturation of part of the fruits in this treatment, which may have increased the problem relative to the harvesting period. In general, the longer the period of interruption of irrigation prior to harvest, the lower the yield. Increase in the period without irrigation prior to harvest does not mean increase in the yield of mature fruits of 'BRS Sena' tomato.

Similar results were found in Italy by Patanè et al. (2011), who observed that irrigation suspension before harvest leads to lower crop yields and that irrigation during the entire cycle of tomato plants cause higher yields, and in Morrinhos, GO, by Silva et al. (2018), who concluded that the higher the water stress index, the lower the yield of the hybrid 'BRS Sena'.

In both studies, the longer the period without irrigation prior to harvest, the lower the incidence of green fruits (Figures $4 \mathrm{~A}$ and $\mathrm{B}$ ). On the other hand, \%RFY showed different responses from one year to the other. In the first year, the greater the number of days without irrigation before harvest, the higher the incidence of rotten fruits (Figure 4A). In the second year, the lowest incidence of rotten fruits and highest

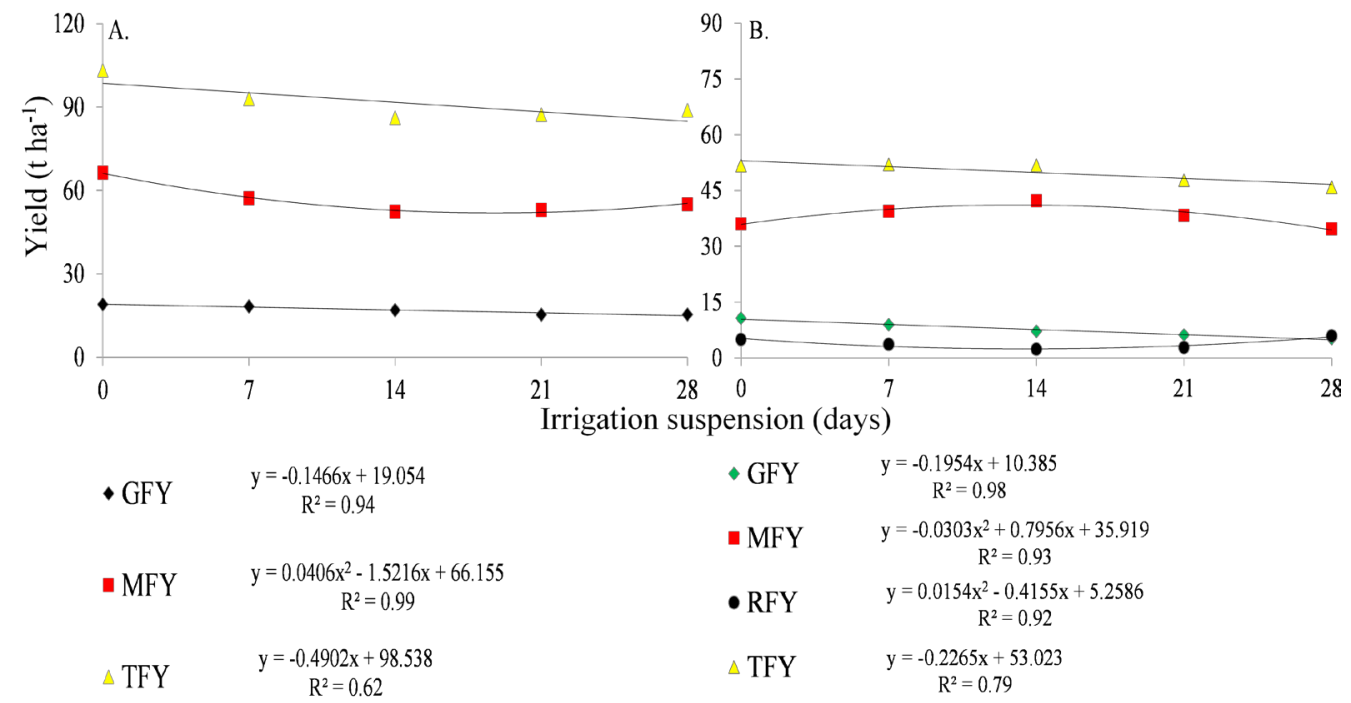

Figure 3. Green fruit yield (GFY), mature fruit yield (MFY) and total fruit yield (TFY), in 2015 (A) and in 2016 (B), of tomato plants at 125 DAT, as a function of irrigation suspension prior to harvest, in Morrinhos, GO, Brazil

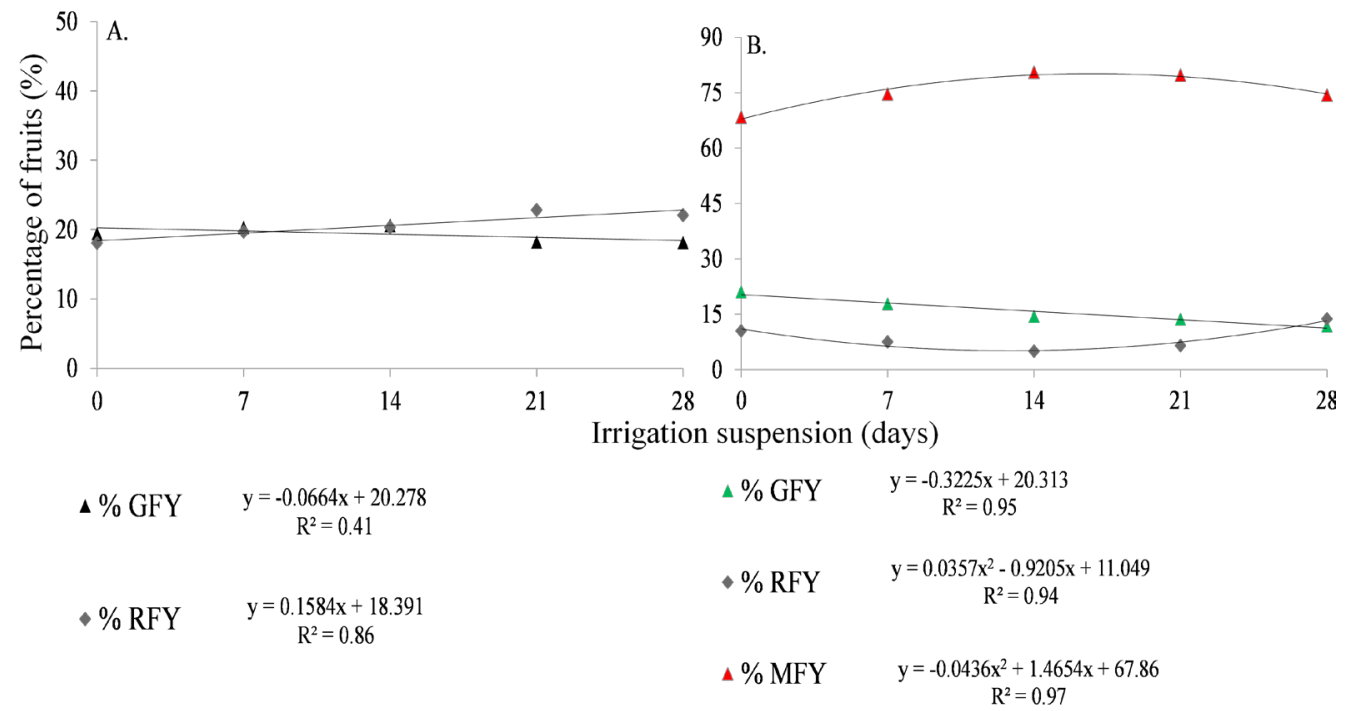

Figure 4. Percentage of yields of green (\% GFV) and rotten (\% RFY) fruits in 2015 (A) and in 2016 (B), of tomato plants at 125 DAT, as a function of irrigation suspension prior to harvest, in Morrinhos, GO, Brazil 


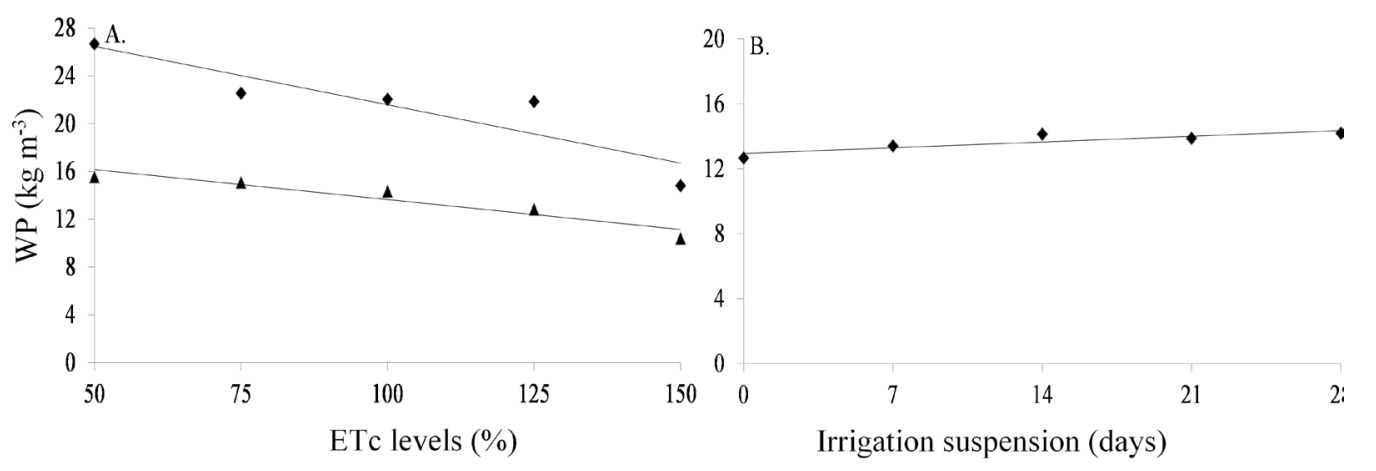

$\begin{array}{cc}\text {-WP 2015 } & y=-0.0977 x+31.351 \\ R^{2}=0.82\end{array}$

-WP $2016 \quad y=0.0504 x+12.943$
$R^{2}=0.77$

Figure 5. Water productivity (WP) in 2015 and 2016 of tomato plants at 125 DAT, subjected to irrigation replacement levels (\%ETc) (A) and WP in 2016 (B), as a function of irrigation suspension period prior to harvest, in Morrinhos, GO, Brazil

incidence of mature fruits (5.12 and $80.17 \%$ ) were estimated when irrigation was suspended at 13 and 17 days before harvest, respectively, although there is a trend of increase in rotten fruits and reduction of mature fruits as the period without irrigation before harvest becomes longer (Figure 4B).

The increase of fruit rotting in treatments with longer period without irrigation before harvest is probably related to the early maturation and higher temperatures, which in turn are associated with the water deficit of the plants, which caused softening in the fruits and rotting. It is evident that, as the percentage of mature fruits decreases, there is an increment in the number of rotten fruits due to the longer period without irrigation before harvest (Figure 4B).

Regardless of the evaluation year (2015 or 2016), the highest values of WP were 15.55 and $12.65 \mathrm{~kg} \mathrm{~m}^{-3}$, which occurred with the lowest irrigation replacement (50\% ETc) (Figure 5A). In relation to irrigation suspension prior to harvest, in 2016 the longer the number of days without irrigation before harvest (28 days), the higher the water productivity (Figure 5B).

The results found are similar to those observed by Patanè et al. (2011) in the region of Sicily - Italy, and Nangare et al. (2016) in India, who verified that, under water deficit, the tomato crop is more efficient in using water, a result also found by Bacallao \& Fundora (2014).

\section{Conclusions}

1. Highest tomato yields were obtained with water replacements ranging from 125.47 and $132.11 \%$ ETc, in the first and second year, respectively.

2. Deficit irrigation allows water saving, but significantly reduces the yield of the hybrid 'BRS Sena'.

3. Growing plants under water deficit and excess increased the incidence of rotten fruits and decreased the incidence of mature fruits.

4. Irrigation suspension prior to harvest decreased crop yield, increased the incidence of rotten fruits and decreased the incidence of green fruits.

5. Highest water productivity by the crop occurred under water deficit conditions, a management that may be interesting for regions with water restrictions.

\section{ACKNOWLedgements}

Thanks to the Instituto Federal de Goiás for supporting the planting and conduction of the experiment and submission of the scientific paper. Thanks to the Brambilla and Heringer industries, for providing the tomato seedlings and fertilizers required in the study, respectively.

\section{Literature Cited}

Allen, R. G.; Pereira, L. S.; Raes, D.; Smith, M. Crop evapotranspiration: Guidelines for computing crop water requirements. Rome: FAO, 1998. 300p. Irrigation and Drainage, Paper 56

Bacallao, M. F.; Fundora, L. B. Tolerncia a estrés por déficit hídrico em tomate (Solanum lycopersium L.). Cultivos Tropicales, v.35, p.70-88, 2014.

CFSGO - Comissão de Fertilidade de Solos de Goiás. Recomendações de corretivos e fertilizantes para Goiás: 5. aproximação. Goiânia: CFSGO, 1988. 10p. Informativo Técnico, 1

EMBRAPA - Empresa Brasileira de Pesquisa Agropecuária. Sistema brasileiro de classificação de solo. 3.ed. rev. ampl. Brasília: Embrapa Informação Tecnológica, 2013. 353p.

Ferreira, D. F. Sisvar: A computer statistical analysis system. Ciência e Agrotecnologia, v.35, p.1039-1042, 2011. https://doi.org/10.1590/ S1413-70542011000600001

Inoue-Nagata, A. K. Doenças viróticas. In: Lopes, C. A.; Ávila, A. C. de. (orgs.). Doenças do tomateiro. Brasília: Embrapa Hortaliças, 2005. p.77-94.

Koetz, M.; Masca, M. G. C. C.; Carneiro, L. C.; Ragagnin, V. A.; Sena Júnior, D. G. de; Gomes Filho, R. R. Produção de tomate industrial sob irrigação por gotejamento no sudeste de Goiás. Revista Brasileira de Agricultura Irrigada, v.2, p.9-15, 2008. https://doi. org/10.7127/rbai.v2n100020

Koetz, M.; Masca, M. G. C. C.; Carneiro, L. C.; Ragagnin, V. A.; Sena Júnior, D. G. de; Gomes Filho, R. R. Caracterização agronômica e ${ }^{\circ}$ Brix em frutos de tomate industrial sob irrigação por gotejamento no sudeste de Goiás. Revista Brasileira de Agricultura Irrigada, v.4, p.14-22, 2010. https://doi.org/10.7127/rbai.v4n100028

Monte, J. A.; Pacheco, A. de S.; Medici, L. O.; Carvalho, D. F. de; Pimentel, C. Growth analysis and yield of tomato crop under different irrigation depths. Revista Brasileira de Agricultura Irrigada, v.17, p.926-931, 2013. https://doi.org/10.1590/S1415-43662013000900003 
Morales, R. G. F.; Resende, L. V.; Bordini, I. C.; Galvão, A. G.; Rezende, F. C. Caracterização do tomateiro submetido ao déficit hídrico. Scientia Agraria, v.16, p.9-17, 2015. https://doi.org/10.5380/rsa. v16i1.41042

Moreira, J. A. A.; Cardoso, A. F.; Costa, L. L.; Rodrigues, M. S.; Peixoto, N.; Braz, L. T. Manejo da irrigação para otimização da produtividade qualidade de frutos de tomateiro em sistema de plantio direto. Irriga, v.17, p.408-417, 2012. https://doi. org/10.15809/irriga.2012v17n4p408

Nangare, D. D.; Singh, Y.; Kumary, P. S.; Minhas, P. S. Growth, fruit yield and quality of tomato (Lycopersicon esculentum Mill.) as affected by deficit irrigation regulated on phenological basis. Agricultural Water Management, v.171, p.73-79, 2016. https:// doi.org/10.1016/j.agwat.2016.03.016

Patanè, C.; Tringali, S.; Sortino, O. Effects of deficit irrigation on biomass, yield, water productivity and fruit quality of processing tomato under semi-arid Mediterranean climate conditions. Scientia Horticulturae, v.129, p.590-596, 2011. https://doi. org/10.1016/j.scienta.2011.04.030
Rebouças Neto, M. de O.; Azevedo, B. M. de; Sousa, G. G. de; Mesquita, J. B. R. de; Viana, T. V. de A.; Fernandes, C. N. V. Irrigação da cultura do tomateiro durante dois anos de cultivo no litoral de Fortaleza-CE. Revista Brasileira de Agricultura Irrigada, v.11, p.1548-1556, 2017. https://doi.org/10.7127/rbai.v11n400598

Sá, N. S. A. de; Pereira, G. M.; Alvarenga, M. A. R.; Mattioli, W.; Carvalho, J. de A. Comportamento da cultura do tomateiro sob diferentes tensões de água no solo em ambiente protegido. Revista Brasileira Engenharia Agrícola e Ambiental, v.9, p.341-347, 2005. https://doi.org/10.1590/S1415-43662005000300008

Silva, C. J. da; Silva, C. A. da; Freitas, C. A. de; Golynski, A.; Silva, L. F. da; Frizzone, J. A. Tomato water stress index as a function of irrigation depths. Revista Brasileira Engenharia Agrícola e Ambiental, v.22, p.95-100, 2018. https://doi.org/10.1590/18071929/agriambi.v22n2p95-100

Silva, J. A. da; Dutra, A. F.; Cavalcante, N. M. da S.; Melo, A. S. de; Silva, F. G. da; Silva, J. M. da. Aspectos agronômicos do tomateiro "Caline Ipa 6" cultivado sob regimes hídricos em área do semiárido. Revista Agro@mbiente On-line,v.8, p.336-344, 2014. https://doi.org/10.5327/Z1942-847020140001951 